\title{
The Immunopathology of Human Schistosomiasis-III. Immunoglobulin Isotype Profiles and Response to Praziquantel
}

\author{
Romelia M Ramírez ${ }^{+}$Evelia Ceballos, Belkisyolé Alarcón de Noya*, \\ Oscar Noya*, Nicolás Bianco
}

Instituto de Inmunología y *Sección de Biohelmintiasis, Instituto de Medicina Tropical, Facultad de Medicina, Universidad Central de Venezuela, Apartado Postal 50109, Caracas 1051-A, Venezuela

Immunoglobulin (Ig) isotype ( $\operatorname{Ig} G, \operatorname{Ig} G_{1}, \operatorname{Ig} G_{2}, \operatorname{Ig} G_{3}, \operatorname{Ig} G_{4}, \operatorname{IgM}, \operatorname{IgD}$ and $\operatorname{IgE}$ ) levels were investigated, both pre- and post-treatment with praziquantel (PZQ), in 43 adults and children chronically infected with Schistosoma mansoni, by means of a two-site, isotype-specific immunoenzymometric assay. The patients were classified as responders $(R)$ or non-responders $(N R)$ on the basis of their circumoval precipitin test (COPT) results 12 months after treatment.

In comparison with controls, pre-treatment $R$ children showed significantly higher levels of IgG, $\operatorname{Ig} G_{1}, \operatorname{IgG}_{4}(p<0.001)$ and $\operatorname{IgE}(p<0.01)$, and diminished $\operatorname{Ig} G_{2}(p<0.05)$, while NR children showed significantly elevated levels only of $\operatorname{IgE}(p<0.05)$. Twelve months after therapy, $R$ children maintained significantly lower levels of $\operatorname{Ig} G_{2}$, but showed significantly decreased levels of $\operatorname{Ig} G, \operatorname{Ig} G_{1}, \operatorname{Ig} G_{4}$, and $\operatorname{IgE}$, while the Ig isotype profile of NR children was unaltered.

Adult $R$ and NR showed similar isotype profiles before chemotherapy, with the exception of significantly elevated IgM levels in $R$. Twelve months after therapy, $R$ adults showed significantly decreased levels of $\operatorname{IgG}, \operatorname{Ig} G_{1}$, and $\operatorname{Ig} G_{4}$, while NR adults showed only diminshed $\operatorname{IgG}_{4}$ levels.

These results reveal different Ig isotype profiles in untreated adults and children chronically infected with $\mathrm{S}$. mansoni. The results further show that the pre-treatment Ig isotype profile may be significantly modified after an effective $R$ to chemotherapy, accounted for by down regulation of the $I g G_{1}$ isotype in association with negative seroconversion of the COPT in R patients. The COPT reaction has been associated with the highly specific egg glycoprotein antigen $\omega_{l}$, which shows a significant reduction in reactivity six months after treatment. IgG $G_{1}$ may thus play a main role in the response against the $\omega_{1}$ antigen.

Key words: isotypes - immunoglobulin - Schistosoma mansoni - praziquantel

The role of the cellular and humoral immune response against Schistosoma mansoni infection has been well characterized by several laboratories (Colley et al. 1977, Butterworth 1987, Butterworth et al. 1987, Mendlovic et al. 1987, Aldrey et al. 1988, Benarroch et al. 1988, Butterworth et al. 1988). Hypergammaglobulinemia is a common feature of this response, with consistently elevated total serum IgG (mainly $\mathrm{IgG}_{1}$ and $\left.\mathrm{IgG}_{4}\right)$ and $\mathrm{IgE}$ concentrations in untreated, chronically infected individuals (Iskander et al. 1981, Jassim et al. 1987, Evengard et al. 1988, Boctor \& Peter 1990).

\footnotetext{
This work was supported by the GENIC Program and the National Council of Investigations on Science and Technology (CONICIT)

+Corresponding author. Fax: (582) 6720371

Received 25 April 1995

Accepted 27 May 1996
}

Resistance to reinfection by $S$. mansoni after chemotherapy was investigated in Kenyan school children, in whom the existence of a specific acquired immunity was postulated. When patients susceptible to reinfection were compared with those who were able to eliminate the parasite, it was found that mean antibody levels were higher in the former group. After six months, the titre of specific antibodies against surface antigens declined and remained relatively constant over a period of 18 months in both groups. It was not clear, however, whether this finding was associated with, or independent of, reinfection (Butterworth et al. 1985).

It has also been demonstrated that $\operatorname{IgM}$ and certain IgG isotypes can act as blocking antibodies, preventing the expression of an efficacious protective immunity. These antibodies appear to be elicited in response to egg polysaccharide antigens, and cross-react with glycosylated epitopes located on the schistosomulum surface (Butterworth, 1987). 
Rihet et al. (1991) measured enhanced antiparasite IgE levels in subjects resistant to reinfection with S. mansoni, and found that reinfection occurred when patients produced high levels of antibodies which could compete with IgE. A similar conclusion, suggesting a positive effect of $\mathrm{IgG}_{4}$ in reinfection by $S$. haematobium, was proposed by Hagan et al. (1991), while Demeure et al. (1983) showed that resistance to reinfection after oxamniquine (OX) chemotherapy was associated positively with $\mathrm{IgE}$ and negatively with $\mathrm{IgG}_{2}$ and $\mathrm{IgG}_{4}$ anti-larval antibodies. These results suggest that $\mathrm{IgE}$ and $\mathrm{IgG}_{4}$ may be antagonistic in protection against schistosoma infection.

Massive chemotherapy with OX or PZQ (Cline et al. 1982, Andrews et al. 1983, Cioli et al. 1993) has been one of the most important measures in the control of schistosomiasis in endemic areas. While resistance to OX is well docummented, such has not been the case for PZQ. Nevertheless, there have been reports of possible failures in the treatment of humans infected with $S$. mansoni in Brazil (Tavares Neto \& Prata 1988, Katz et al. 1991) and Senegal (Anonymous 1992), and of induction of resistance in mice (Fallon \& Doenhoff 1994).

Although published reports suggest that PZQ alone is capable of killing or damaging adult schistosoma in vitro (Xiao et al. 1985), other evidence strongly indicates that anti-schistosome antibodies potentiate the effect of PZQ in vivo (Xiao et al. 1985, Brindley \& Sher 1987, Mondha et al. 1990). However, a clear relationship between response to PZQ and the host Ig isotype profile has not yet been established. Studies in mice infected with $S$. mansoni have shown that the efficacy of PZQ against this parasite is probably linked to the host immune response. In fact, considerably less effective schistosomicide activity has been observed by Sabah et al. (1985) in adult thymectomized mice treated with anti-thymocyte sera, in comparison with intact animals.

As part of an ongoing research protocol on the immunopathology of $S$. mansoni (Aldrey et al. 1988, Benarroch et al. 1988, Alarcón de Noya et al. 1992, Noya et al. 1995a, b), we present herein the results of an immunoglobulin isotype level quantitation study undertaken in Venezuelan patients chronically infected with $S$. mansoni. Our results suggest a possible relationship between response to PZQ and a given isotype profile.

\section{MATERIALS AND METHODS}

Patients - Forty-three subjects chronically infected with $S$. mansoni were selected for the study, by means of a clinical, parasitological, and immunological protocol standardized by the Biohelminthiasis Section of the Institute of Tropi- cal Medicine (Caracas, Venezuela). The subjects, including 22 children (aged 8-12 years) and 21 adults (aged 18-40 years), came from the town of Caraballeda, an isolated focus of schistosomiasis on the northern shore of Venezuela. The possibility of reinfection was avoided by subsequent elimination of schistosomiasis transmission by implementation of environmental sanitation and massive PZQ treatment programs.

All patients received PZQ in a single oral dose of $40 \mathrm{mg} / \mathrm{kg}$, and were reevaluated 3, 6, 9, and 12 months after treatment (Alarcón de Noya et al. 1992, Noya et al. 1995a, b). Of the 43 patients, 27 (14 children and 13 adults) responded to PZQ (responders, R) while 16 patients ( 8 children and 8 adults) remained infected one year after treatment with PZQ (non-responders, NR), as assessed by the circumoval precipitin test (COPT) (OliverGonzalez 1954, Alarcón de Noya et al. 1992, Noya et al. 1995a, b). Thirty-seven healthy individuals, including 12 children (aged 8-12 years) and 25 adults (aged 16-42 years) free of schistosomal infections, were selected as the control group after evaluation under the same protocol.

Parasitological and specific immunodiagnostic assessment - Stool examination was performed by a formol-ether assay (Martin \& Beaver 1968) and quantified by the Kato-Katz technique (Katz et al. 1972). From each subject, two fecal samples were collected on different days before, and two after, treatment. Three conventional Kato tests were performed on each fecal sample. Antibodies to $S$. mansoni were detected in sera by both COPT (with a $10 \%$ cut-off level) and ELISA assays using soluble $S$. mansoni egg and adult worm antigens (Alarcón de Noya et al. 1992).

Immunoglobulin isotypes - The immunoglobulin isotypes were measured by a two-site immunoenzymometric assay, specific for each Ig isotype, as previously described by Black et al. (1988) and Reimer et al. (1988). Briefly, patients Igs were captured by a human isotype-specific mouse monoclonal antibody bound to the plastic surface of Immulon II 96-well microtest plates (Dynatech, Alexandria, VA). The presence of each isotype was quantitated using a mixture of peroxidase-conjugated monoclonal antibodies (kindly provided by the late Dr CB Reimer of the Centers for Disease Control, Atlanta, GA) to the kappa, lambda, and/or other appropriate Ig epitopes.

The World Health Organization (WHO) International Standard for human IgG, IgA and IgM, 67/97 (Rowe et al. 1972), was used to establish the numerical basis for the $\mathrm{IgG}, \mathrm{IgG}_{1}, \mathrm{IgG}_{2}, \mathrm{IgG}_{3}$, and $\mathrm{IgG}_{4}$ assays, using the mass units assigned by Klein et al. (1985). For IgA and IgM, the mass units used were the International Units estimated for these two 
analytes by Reimer et al. (1982). IgD and IgE calibration was performed using the British Research Standard, 67/37 (Rowe et al. 1970), and the WHO International Reference Standard, 67/204 (Rowe et al. 1973), respectively. Duplicates of the quality control preparation for each isotype were systematically included to estimate inter- and intra-assay variability.

Data analysis - Standard curves for each analyte were constructed using a public domain BASIC computer program, as described by Black et al. (1988), allowing an accurate computer interpolation of unknowns. Statistical analysis was performed by Student test for paired and unpaired samples; a linear correlation test and Wilcoxon range test were also used.

\section{RESULTS}

Parasitological and COP test - Results of the parasitological and standard immunodiagnostic evaluations of R and NR adults and children are presented in Table I. The parasitic load of these patients was low: only 2 of 22 children and 1 of 21 adults eliminated more than 100 eggs/g of feces. Posttreatment stool examinations were negative in both groups. The pretreatment COPT was positive in all the patients, while posttreatment values were below $10 \%$ in the R group and above $10 \%$ in the NR group.

Immunoglobulin isotype levels - a) Children vs. controls - In comparison with the control group, the pretreatment $\mathrm{R}$ children showed significantly higher levels of $\operatorname{IgG}, \operatorname{IgG}_{1}, \operatorname{IgG}_{4}$, and $\mathrm{IgE}$, and lower levels of $\operatorname{IgG}_{2}$, while the NR children exhibited significantly elevated levels only of $\operatorname{IgE}$ (Table II). When pretreatment sera from R and NR children were compared, the former showed signifi-
TABLE I

Immunoparasitological characteristics of chronic Schistosoma mansoni-infected patients

\begin{tabular}{|c|c|c|c|c|}
\hline \multirow{2}{*}{$\begin{array}{l}\text { Groups } \\
\text { of } \\
\text { patients }\end{array}$} & \multirow[b]{2}{*}{$\mathrm{n}$} & \multirow{2}{*}{$\begin{array}{c}\text { Intensity of } \\
\text { infection } \\
\text { eggs/g feces } \\
\mathrm{x} \pm \mathrm{s} \\
\mathrm{bt} / \mathrm{at}\end{array}$} & \multicolumn{2}{|c|}{$\operatorname{COPT}(\%)$} \\
\hline & & & $\begin{array}{c}\mathrm{x} \pm \mathrm{s} \\
\mathrm{bt}\end{array}$ & $\begin{array}{c}\mathrm{x} \pm \mathrm{s} \\
\text { at }\end{array}$ \\
\hline $\mathrm{R}$ children & 14 & $57 \pm 62 / 0$ & $44 \pm 14$ & $3 \pm 3$ \\
\hline NR children & 8 & $33 \pm 23 / 0$ & $34 \pm 14$ & $25 \pm 8$ \\
\hline $\mathrm{R}$ adults & 13 & $44 \pm 23 / 0$ & $42 \pm 20$ & $1 \pm 2$ \\
\hline NR adults & 8 & $51 \pm 55 / 0$ & $47 \pm 15$ & $33 \pm 13$ \\
\hline
\end{tabular}

COPT: Circumoval Precipitin Test; bt/at: before/after praziquantel treatment; $\mathrm{x} \pm \mathrm{s}$ : mean \pm standard deviation; R/NR: responder/non-responder to praziquantel chemotherapy.

cantly higher levels of $\operatorname{IgG}$ and $\operatorname{IgG}_{1}(\mathrm{p}<0.05)$, and lower levels of $\operatorname{IgG}_{2}(\mathrm{p}<0.05)$; differences between other isotypes were not significant. b) Adults vs. controls - In comparison with controls, baseline pretreatment isotype levels in $\mathrm{R}$ and $\mathrm{NR}$ adults showed similarly high concentrations of $\mathrm{IgG}, \mathrm{IgG}_{1}$, $\mathrm{IgG}_{3}, \mathrm{IgG}_{4}$, and $\mathrm{IgE}$. IgM was significantly higher only in $\mathrm{R}$ patients. After treatment, the $\mathrm{R}$ patients maintained high levels of $\mathrm{IgG}, \mathrm{IgG}_{1}, \mathrm{IgG}_{3}$, and $\mathrm{IgE}$, while only IgG and IgE remained significantly elevated in NR patients (Table III). c) Baseline vs. post-treatment comparison - When the pretreatment baseline levels of isotypes were compared with the values at 12 months after therapy, R children showed significantly decreased levels, although still significantly higher than controls, of $\operatorname{IgG}(\mathrm{p}<0.0001), \operatorname{IgG}_{1}(\mathrm{p}<0.05), \operatorname{IgG}_{4}(\mathrm{p}<0.05)$, and

TABLE II

Immunoglobulin isotypes in children before and after treatment

\begin{tabular}{|c|c|c|c|c|c|}
\hline \multirow[t]{2}{*}{ Ig } & \multirow{2}{*}{$\begin{array}{l}\text { Controls } \\
\qquad x \pm s\end{array}$} & \multicolumn{2}{|c|}{ Responders } & \multicolumn{2}{|c|}{ Non-responders } \\
\hline & & $\begin{array}{c}\mathrm{bt} \\
\mathrm{x} \pm \mathrm{s}\end{array}$ & $\begin{array}{c}\text { at } \\
x \pm s\end{array}$ & $\begin{array}{c}\text { bt } \\
x \pm s\end{array}$ & $\begin{array}{c}\text { at } \\
\mathrm{x} \pm \mathrm{s}\end{array}$ \\
\hline $\mathrm{IgG}$ & $13.2 \pm 2.6$ & $16.2 \pm 2.6^{a}$ & $13.7 \pm 2.6$ & $14.4 \pm 2.4$ & $13.2 \pm 1.9$ \\
\hline $\mathrm{IgG}_{1}$ & $9.3 \pm 2.1$ & $12.8 \pm 2.8^{a}$ & $10.3 \pm 2.7^{b}$ & $9.7 \pm 1.7$ & $9.5 \pm 1.3$ \\
\hline $\mathrm{IgG}_{2}$ & $2.5 \pm 1.0$ & $1.7 \pm 0.7^{b}$ & $1.7 \pm 0.7^{b}$ & $2.1 \pm 0.5$ & $2.3 \pm 0.6$ \\
\hline $\mathrm{IgG}_{3}$ & $0.6 \pm 0.4$ & $0.7 \pm 0.31$ & $0.7 \pm 0.4$ & $0.5 \pm 0.3$ & $0.6 \pm 0.4$ \\
\hline $\mathrm{IgG}_{4}$ & $0.6 \pm 0.4$ & $1.7 \pm 1.4^{a}$ & $0.8 \pm 0.5^{b}$ & $1.6 \pm 1.8$ & $0.8 \pm 0.9$ \\
\hline $\operatorname{IgM}$ & $1.3 \pm 0.4$ & $1.2 \pm 0.6$ & $1.3 \pm 0.7$ & $1.2 \pm 0.6$ & $1.2 \pm 0.5$ \\
\hline $\operatorname{IgA}$ & $2.3 \pm 0.7$ & $1.9 \pm 0.6$ & $1.7 \pm 0.7$ & $1.8 \pm 0.7$ & $1.7 \pm 0.6$ \\
\hline $\operatorname{IgD}$ & $0.07 \pm 0.04$ & $0.108 \pm 0.09$ & $0.109 \pm 0.08$ & $0.07 \pm 0.05$ & $0.08 \pm 0.04$ \\
\hline $\mathrm{IgE}$ & $211 \pm 72$ & $465 \pm 416^{c}$ & $375 \pm 199^{b}$ & $363 \pm 217$ & $310 \pm 199$ \\
\hline
\end{tabular}

$\mathrm{p}$ value in comparison with the control group: $a$ : $\mathrm{p}<0.001, b: \mathrm{p}<0.05, c: \mathrm{p}<0.01$; bt/at: before/after treatment; IgG, $\mathrm{IgG}_{1}, \mathrm{IgG}_{2}, \mathrm{IgG}_{3}, \mathrm{IgG}_{4}, \mathrm{IgM}$, and $\mathrm{IgA}$ are expressed in $\mathrm{mg} / \mathrm{ml}$, IgE in $\mathrm{IU} / \mathrm{ml}$, and $\mathrm{IgD}$ in $\mu \mathrm{g} / \mathrm{ml}$. 
TABLE III

Immunoglobulin isotypes in adults before and after treatment

\begin{tabular}{|c|c|c|c|c|c|}
\hline \multirow[t]{3}{*}{$\operatorname{Ig}$} & \multirow{3}{*}{$\begin{array}{l}\text { Controls } \\
\qquad \mathrm{x} \pm \mathrm{s}\end{array}$} & \multicolumn{2}{|c|}{ Responders } & \multicolumn{2}{|c|}{ Non-responders } \\
\hline & & bt & at & $\mathrm{bt}$ & at \\
\hline & & $\mathrm{x} \pm \mathrm{s}$ & $\mathrm{x} \pm \mathrm{s}$ & $\mathrm{x} \pm \mathrm{s}$ & $\mathrm{x} \pm \mathrm{s}$ \\
\hline $\mathrm{IgG}$ & $11.3 \pm 1.9$ & $16.9 \pm 2.7^{a}$ & $13.4 \pm 2.6^{c}$ & $16.1 \pm 3.5^{a}$ & $14.1 \pm 3.2^{c}$ \\
\hline $\mathrm{IgG}_{1}$ & $7.4 \pm 1.5$ & $10.4 \pm 2.3^{a}$ & $8.8 \pm 1.8^{b}$ & $10.4 \pm 2.8^{a}$ & $9.6 \pm 3.6$ \\
\hline $\mathrm{IgG}_{2}$ & $2.3 \pm 1.1$ & $2.6 \pm 1.6$ & $2.9 \pm 2.0$ & $2.8 \pm 1.2$ & $2.6 \pm 0.6$ \\
\hline $\mathrm{IgG}_{3}$ & $0.4 \pm 0.2$ & $0.7 \pm 0.2^{a}$ & $0.7 \pm 0.3^{a}$ & $0.8 \pm 0.4^{a}$ & $0.7 \pm 0.3$ \\
\hline $\mathrm{IgG}_{4}$ & $0.6 \pm 0.4$ & $1.9 \pm 1.3^{a}$ & $0.8 \pm 0.8$ & $2.4 \pm 1.3^{a}$ & $1.8 \pm 1.2$ \\
\hline $\operatorname{IgM}$ & $1.2 \pm 0.5$ & $1.7 \pm 0.7^{b}$ & $1.9 \pm 0.9^{b}$ & $1.3 \pm 0.7$ & $1.1 \pm 0.7$ \\
\hline $\operatorname{IgA}$ & $2.4 \pm 0.8$ & $2.1 \pm 0.6$ & $2.1 \pm 0.3$ & $2.1 \pm 0.5$ & $1.9 \pm 0.5$ \\
\hline $\operatorname{IgD}$ & $0.06 \pm 0.03$ & $0.08 \pm 0.06$ & $0.06 \pm 0.03$ & $0.08 \pm 0.06$ & $0.06 \pm 0.03$ \\
\hline $\operatorname{IgE}$ & $188 \pm 41$ & $607 \pm 621^{c}$ & $432 \pm 279^{b}$ & $747 \pm 777^{c}$ & $371 \pm 299^{c}$ \\
\hline
\end{tabular}

$\mathrm{p}$ value in comparison with the control group: $a: \mathrm{p}<0.001, b: \mathrm{p}<0.05, c: \mathrm{p}<0.01$; bt/at: before/after treatment; IgG, $\mathrm{IgG}_{1}, \mathrm{IgG}_{2}, \mathrm{IgG}_{3}, \mathrm{IgG}_{4}, \mathrm{IgM}$, and $\mathrm{IgA}$ are expressed in $\mathrm{mg} / \mathrm{ml}$, IgE in IU/ml, and $\mathrm{IgD}$ in $\mu \mathrm{g} / \mathrm{ml}$.

$\operatorname{IgE}(\mathrm{p}<0.01)$, with consistently lower levels of $\mathrm{IgG}_{2}$ $(\mathrm{p}<0.05)$. In NR children, only $\mathrm{IgG}_{4}$ levels were decreased $(p<0.05)$.

The adult $\mathrm{R}$ patients had decreased levels of $\operatorname{IgG}(\mathrm{p}<0.001), \operatorname{IgG}_{1}(\mathrm{p}<0.01)$, and $\operatorname{IgG}_{4}(\mathrm{p}<0.001)$, while in NR adults, the levels of $\operatorname{IgG}(\mathrm{p}<0.001)$, $\operatorname{IgG}_{4}(\mathrm{p}<0.001)$, and $\operatorname{IgE}(\mathrm{p}<0.05)$ were significantly decreased.

Correlations between immunoglobulin isotypes and immunoparasitological parameters - Among $\mathrm{R}$ children, a significant positive correlation was observed before treatment between COPT and both $\operatorname{IgG}_{4}(\mathrm{p}<0.001)$ and parasitic load $(\mathrm{p}<0.001)$, while NR children showed a significant positive correlation before treatment between COPT and the levels of $\operatorname{IgM}(\mathrm{p}<0.01), \operatorname{IgD}(\mathrm{p}<0.025)$, and $\operatorname{IgE}$ $(\mathrm{p}<0.025)$.

Among adults, a positive correlation before treatment was found only in $\mathrm{R}$ patients, between parasitic load and $\mathrm{IgG}_{4}$ levels $(\mathrm{p}<0.05)$.

\section{DISCUSSION}

To gain further insight into the possible relationship between Ig isotype levels and response to PZQ therapy, we evaluated, by means of a high performance, two-site immunoenzymometric assay (Black et al. 1988, Reimer et al. 1988), the preand post-PZQ treatment serum immunoglobulin isotypic profiles of a group of 43 patients (both children and adults) chronically infected with $S$. mansoni.

This investigation was conducted in an isolated focus of schistosomiasis in northern Venezuela, where the patients presented with prevailing chronic infections and low egg counts. It was possible to halt the spread of $S$. mansoni infection in this area by eradicating the intermediate host of $S$. mansoni by both the application of molluscicides and the introduction, into the river snails of the Thiaridae family, of competitors capable of reducing, and even eliminating, the population of $B$. glabrata (Pointer \& McCullough 1989). Over the course of the study, B. glabrata was not detected in the river, and no new infections were identified in individuals under four years of age. We therefore assume that the subjects included in our protocol were not affected by episodes of reinfection during the post-treatment evaluation period. Thus, effects on isotype levels were dependent on the natural progression of the chronic infection by $S$. mansoni and on the action of both the host immune response to the parasite and the PZQ therapy.

In patients eliminating more than $100 \mathrm{eggs} / \mathrm{g}$ of feces, stool examination has conventionally been considered the best measure of the effectiveness of chemotherapy (WHO 1995). The sensitivity of the parasitological methods diminishes, however, when individuals excrete less than $100 \mathrm{eggs} / \mathrm{g}$ of feces (Mott \& Cline 1980, Alarcón de Noya et al. 1992). In this situation, the immunodiagnostic tests seem to better assess the presence of the parasite. Among this kind of test, the COPT and methods based on the detection of circulating antigens have been extensively used. However, the antigen-detecting techniques are not yet of sufficiently high sensitivity in cases of low parasitic burden (De Jonge et al. 1991). The COP test, however, is both highly specific and sensitive, and has the additional advantage of demonstrating negative seroconversion after successful treatment, as has been shown in both mice (Cancio et al. 1967) and humans (Rifaat et al. 1969, Alarcón de Noya et al. 1992). 
We have previously demonstrated that patients over five years of age and with an excretion rate lower than $100 \mathrm{egg} / \mathrm{g}$ of feces were correctly identified by COPT, with sensitivities higher than $90 \%$. In children under five years of age, COPT sensitivity was $86 \%$ (Alarcón de Noya et al. 1992). In the current study, all of the patients were positive by COPT before treatment, and on initial observation, we could not establish any baseline differences among patients. Twelve months after treatment, all of the patients were negative for $S$. mansoni eggs. However, $48.4 \%$ of the patients dropped below the COPT cut-off value of $10 \%$, while $48.5 \%$ remained positive. On this basis, we identified two main groups of patients: "responders" (R), characterized by negative COPT conversion, and "non-responders" (NR), who remained COPT-positive.

Previous studies (Rihet et al. 1991, Hagan et al. 1991, Demeure et al. 1993) of resistant and susceptible subjects revealed that resistance to reinfection was associated with enhanced $\operatorname{IgG}$ and $\operatorname{IgE}$ levels, and occurrence of reinfection, with high levels of $\operatorname{IgG}_{4}$ and $\operatorname{IgG}_{2}$. It has also been postulated that $\mathrm{IgG}_{4}$ and $\mathrm{IgG}_{2}$ may compete with effective isotypes, such as $\operatorname{IgE}$ and $\operatorname{IgG}_{1}$, thereby blocking the host immune response against the parasite.

Jassin et al. (1987) found that Sudanese children from an area highly endemic for $S$. mansoni had elevated levels of IgG and IgE in comparison with a normal European population. Additionally, they reported that a significant part of the overall $\mathrm{IgG}$ increase was accounted for by $\operatorname{IgG}_{1}, \mathrm{IgG}_{3}$, and $\mathrm{IgG}_{4}$, associated with an increase of $\operatorname{IgA}$ and $\operatorname{IgM}$. The IgG isotype profile in response to PZQ was not evaluated.

Demeure et al. (1993) suggested that resistance to reinfection is influenced by the balance between a protective effect of $\operatorname{IgE}$ and a negative action of $\mathrm{IgG}_{4}$ and $\mathrm{IgG}_{2}$ antibodies to carbohydrate determinants on schistosomula. Rihet et al. (1992) demonstrated that certain antibodies present in the sera of chronically infected subjects compete with $\operatorname{IgE}$ antigen-binding, and that $\mathrm{IgG}_{4}$ accounts for most of this blocking activity. They identified the immunoglobulin isotypes $\mathrm{IgE}, \mathrm{IgG}_{4}$, and $\mathrm{IgG}_{2}$ as having a significant role in the human response to $S$. mansoni infection.

In the present study, evaluation of the immunoglobulin isotype profile in both $\mathrm{R}$ and NR patients showed a particular pattern of expression. At presentation, the NR children showed significantly elevated levels of $\operatorname{IgE}(\mathrm{p}<0.05)$ and $\mathrm{IgG}_{4}$ $(p<0.01)$, suggesting a predominant $\mathrm{TH}-2$ response. In the $\mathrm{R}$ children, who presented with significantly increased levels of $\operatorname{IgG}_{1}(\mathrm{p}<0.001), \mathrm{IgG}_{4}(\mathrm{p}<0.01)$, and $\operatorname{IgE}(\mathrm{p}<0.05)$, and a decreased level of $\operatorname{IgG}_{2}$, there was no clear-cut predominance of either a TH-1 or TH-2 response, suggesting a possibly major difference between the two groups of children at presentation (Gascan et al. 1991). Although IgE has been considered to be protective against parasitic infections (Demeure et al. 1993), our findings indicated that increased levels of IgE alone were not sufficient for protection in NR children.

Moreover, in comparing the behavior of the isotype profile after treatment in both groups of children, the diminishment of the level of total $\operatorname{IgG}$ $(\mathrm{p}<0.001)$ in $\mathrm{R}$ patients was found to be due primarily to decreases in $\operatorname{IgG}_{1}(\mathrm{p}<0.001)$ and $\mathrm{IgG}_{4}$ $(\mathrm{p}<0.001)$, with $\mathrm{IgG}_{2}$ levels remaining low, while in NR patients, diminishment of the total level of IgG was due primarily to a reduction in $\mathrm{IgG}_{4}$ $(p<0.001)$. These observations may indicate a specific protective response in $\mathrm{R}$ patients, dependent on the $\mathrm{IgG}_{1}$ and $\mathrm{IgE}$ isotypes, which competes with the blocking effect of $\mathrm{IgG}_{4}$, and that the balance between $\mathrm{IgG}_{4}$ and $\mathrm{IgG}_{1}$ may downregulate the synthesis of $\operatorname{IgG}_{2}$, as suggested by its diminished levels in $\mathrm{R}$ children.

The diminishment of most of the elevated isotype levels found in R children is consistent with previous studies of the specific response against $S$. mansoni egg antigens, which showed weaker recognition, after cure, of most of the electrophoretic bands. In fact, after successful treatment, the majority of the patients did not recognize the Sm-25 molecule (Noya et al. 1995b).

Isotype expression among the group of adult patients did not show differences before treatment between $R$ and NR individuals, with the exception of increased levels of IgM in the R group ( $p<0.02)$. Twelve months after treatment, $\operatorname{IgG}(\mathrm{p}<0.001)$, $\mathrm{IgG}_{1}(\mathrm{p}<0.001)$, and $\operatorname{IgG}_{4}(\mathrm{p}<0.001)$ showed significantly diminished levels, while the increased IgM remained unaltered in the $\mathrm{R}$ group. In the NR group, only the $\mathrm{IgG}_{4}$ level was downregulated $(\mathrm{p}<0.001)$. These findings may also be indicative of the importance of $\mathrm{IgG}_{1}$, and $\mathrm{IgG}_{4}$ in the efficacy of PZQ treatment.

The simultaneous downregulation of $\mathrm{IgG}_{1}$ and IgE levels and negative seroconversion of the COPT in post-treatment $R$ children suggest that both parameters may have a common antigen specificity. The COPT reaction has been associated with a very specific egg glycoprotein antigen, designated $\omega_{1}$, which has been postulated as one of the most promising antigens for diagnosis, because it also correlates with cure (Dune et al. 1981, 1988, 1991, McLaren 1981). The $\omega_{1}$ antigen is one of the most important components of the $S$. mansoni egg antigen, which showed, in immunological tests, a significant reduction in reactivity six months after treatment (Mott \& Dixon 1982). The 
downregulation of $\operatorname{IgG}_{1}$ in the groups of $\mathrm{R}$ patients is very suggestive that this isotype could act synergistically with $\mathrm{PZQ}$, contributing to an effective therapy, as well as contributing to the negative seroconversion of the COPT by participating in reactions with antigens such as $\omega_{1}$.

In conclusion, our results are in agreement with those of previous studies (Jassin et al. 1987, Hagan et al. 1991, Rihet et al. 1991, Demeure et al. 1993), in demonstrating the participation of $\mathrm{IgG}, \mathrm{IgG}_{1}$, $\mathrm{IgG}_{2}, \mathrm{IgG}_{4}$, and $\mathrm{IgE}$ in the response to $S$. mansoni infection, and suggest that the assessment of Ig isotype profile may help to understand the regulatory mechanism of the anti-parasite response in humans subjected to praziquantel treatment.

\section{REFERENCES}

Anonymous 1992. Praziquantel shows unexpected failure in recent schistosomiasis outbreak. TDR News 41: $1-2$.

Alarcón de Noya B, Spencer L, Noya O 1992. Pre- and Post-treatment immunodiagnostic evaluation in human schistosomiasis mansoni. Mem Inst Oswaldo Cruz 87 (Supp IV) 271-276.

Aldrey O, Noya B, Machado I, Noya O, Bianco NE, Perez GE 1988. Immunopathology of human schistosomiasis mansoni I. Immunomodulatory influences on T cell function. Rev Inst Med Trop São Paulo 30: 393-399.

Andrews P, Thomas H, Pohlke R, Seubert J 1983. Praziquantel. Med Res Rev 3: 147-200.

Benarroch LK, Noya O, Noya B, Bianco NE, Blanca I 1988. Immunopathology of human schistosomiasis mansoni II. Rev Inst Med Trop São Paulo 30: 400405.

Black CM, Plikaytis BD, Wells TM, Ramírez RM, Carlone GM, Chilmonczyk BA, Reimer CB 1988. Two sites immunoenzymometric assays for serum IgG subclass infant/maternal ratios at full term. $J$ Immunol Methods 106: 71-81.

Boctor FN, Peter JB 1990. IgG subclasses in human chronic schistosomiasis: Overproduction of schistosome-specific and non-specific $\mathrm{IgG}_{4}$. Clin Exp Immunol 82: 574-578.

Brindley PJ, Scher A 1987. The chemotherapeutic effect of praziquantel against Schistosoma mansoni is dependent on host antibody response. J Immunol 139: 215-220.

Butterworth AE 1987. Immunity in human schistosomiasis. Acta Tropica 44 (Suppl 12) 31-40.

Butterworth AE, Bebsted-Smith R, Capron A, Capron M, Dalton PR, Dunne DW, Grzych JN, Kariuki HC, Khalife J, Koech D, Mugambi M, Ouma JH, Arap Siongok TK, Sturrock RF 1987. Immunity in human schistosomiasis mansoni: prevention by blocking antibodies of the expression of immunity in young children. Parasitology 94: 281-300.

Butterworth AE, Capron M, Cordingley JS, Dalton PR, Dunne DW, Kariuki HC, Kimani G, Koech D, Mugambi M, Ouma JH, Prentice MA, Richardson
BA, Arap Siongok TK, Sturrock RF, Taylor DW 1985. Immunity after treatment of human schistosomiasis mansoni II. Identification of resistant individuals, and analysis of their immune response. Trans R Soc Trop Med Hyg 79: 393-408.

Butterworth AE, Dunne D, Fulford A, Capron M, Khalife J, Capron A, Koech D, Ouma J, Sturrock R 1988. Immunity in human schistosomiasis mansoni: cross reactive $\mathrm{IgM}$ and $\mathrm{IgG}_{2}$ anti-carbohydrate antibodies block the expression of immunity in young children. Biochimie 70: 1053-1063.

Cancio M, Rivera de Sala A, Ramírez de Arellano G, Rodríguez-Molina R 1967. Circumoval antibodies measurements during treatment of experimental schistosomiasis. Am J Trop Med Hyg 16: 729-734.

Cioli D, Pica-Maltoccia L, Archer S 1993. Drug resistance in schistosomes. Parasitol Today 9: 162-166.

Cline BA, Almeida Machado P, Almoatz Billah M, Mao SP, Shao BR 1982. The control of schistosomiasis in Brazil, Egypt and China. Am J Trop Med Hyg 31: 75-102.

Colley DG, Cook JA, Freeman GL, Bartholomew RK, Jordan P 1977. Human response during human schistosomiasis mansoni I. In vitro lymphocyte blastogenic responses to heterogeneous antigenic preparation from schistosome eggs, worms and cercariae. Int Arch Allergs Appl Immun 53: 420-433.

De Jonge N, Rabello ALT, Krijger FW, Kremsher PG, Rocha Katz N, Deelder AM 1991. Levels of the circulanting anodic and cathodic antigens in serum of schistosomiasis patients from Brazil. Trans $R$ Soc Trop Med Hyg 85: 756-759.

Demeuere CE, Rihet P, Abel I, Ouattara M, Bourgois A, Dessein AJ 1993. Resistance to Schistosoma mansoni in humans influence of $\mathrm{IgE} / \mathrm{IgG}_{4}$ balance and $\mathrm{IgG}_{2}$ in immunity to reinfection after chemotherapy. J Inf Dis 168: 1000-1008.

Dunne DW, George V, Hillyger V, Vazquez G 1988. Schistosoma mansoni cationic egg antigens (CEF): Immunoserology with oxamniquine-treated patients and involvement of CEF6 in the circumoval precipitin reaction. Am J Trop Med Hyg 38: 508-514.

Dunne DW, Jones FM, Doenhoff MJ, 1991. The purification, characterization, serological activity and hepatotoxic properties of two cationic glycoproteins (" ${ }_{1}$ and $\mathrm{T}_{1}$ ) from Schistosoma mansoni eggs. Parasitology 103: 225-236.

Dunne DW, Lucas S, Bickle Q, Pearson S, Madgwick L, Bain J, Doenhoff MJ 1981. Identification and partial purification of an antigen $\left(\mathrm{T}_{1}\right)$ from Schistosoma mansoni eggs is putatively hepatotoxic in T-cell deprived mice. Trans $\mathrm{R}$ Soc Trop Med Hyg 75: 54-71.

Evengard B, Hammarstrom L, Smith CIE, Johansson SGO, Linder E 1988. Subclass distribution and IgE responses after treatment in human schistosomiasis. Clin Exp Immunol 73: 383-388.

Fallon PG, Doenhoff MJ 1994. Drug-resistant schistosomiasis: resistance to praziquantel and oxamniquine induced in Schistosoma mansoni in mice is drug specific. Am J Trop Med Hyg 51: 83-88. 
Gascan H, Gauchat JF, Aversa G, Van-Vlasselaer P, de Vries JE 1991. Ati-CD40 monoclonal antibodies or CD4+ T cell clones and IL-4 induce IgG4 and IgE switching in purified human $\mathrm{B}$ cells via different signaling pathways. $J$ Immunol 174: 8-13.

Hagan P, Blumenthal MJ, Dunne D, Simpson AJG, Wilkins MA 1991. Human $\mathrm{IgE}, \mathrm{IgG}_{4}$, and resistance to reinfection with Schistosoma haematobium. $\mathrm{Na}$ ture 349: 243-245.

Iskander R, Das PK, Aalberse RC 1981. $\mathrm{IgG}_{4}$ antibodies in Egyptian patients with schistosomiasis. Int Arch Allergy Appl Immun 66: 200-207.

Jassim A, Hassan K, Catty D 1987. Antibody isotypes in human schistosomiasis mansoni. Parasite Immunology 9: 627-650.

Katz N, Chaves A, Pellegrino J 1972. A simple device for quantitative stool thick smear technique in schisotosomiasis mansoni. Rev Inst Med Trop São Paulo 14: 397-400.

Katz N, Rochas RS, De Soriza CP, Filho PC, Bruce JI, Coles GE, Kinoli GK 1991. Efficacy of alternating therapy with oxamniquine and praziquantel to treat Schistosoma mansoni in children following failure of first treatment. Am J Trop Med Hyg 44: 509-512.

Klein F, Skavaril F, Vermeeren T, Vlug A, Duimel WJ 1985. The quantification of human IgG subclasses for reference preparation. Clin Chem Acta 150: 119.

McLaren ML, Lillywhite JE, Dunne DW, Doenhoff MJ, 1981. Serodiagnosis of human Schistosoma mansoni infections: enhanced sensitivity and specificity in ELISA using a fraction containing $S$. mansoni eggs anti $\mathrm{T}_{1}$ and $\mathrm{T}_{2}$. Trans $R$ Soc Trop Med Hyg 75: 72 79.

Martin LK, Beaver PC 1968. Evaluation of the Kato thick smears technique for the quantitative diagnosis of helmintic. Am J Trop Med Hyg 17: 382-390.

Mendlovic F, Tarrab-Hazdai R, Arnon R 1987. Role of humoral immunity and helper cell involvement in permissiveness to infection of Schistosoma mansoni. Eur J Immunol 17: 1151-1157.

Modha J, Lambertucci JR, Doenhoff MJ, McLaren D 1990. Immune dependence of schistosomicidal chemotherapy: an ultrastructural study of Schistosoma mansoni adult worm exposed to praziquantel and immune serum in vivo. Parasite Immunol 12: 321334.

Mott K, Cline B 1980. Advances in epidemiology survey methodology and techniques in schistosomiasis. Bull WHO 58: 639-647.

Mott KE, Dixon H 1982. Collaborative study on antigens for immunodiagnosis of schistosomiasis. Bull WHO 60: 729-753.

Noya O, Fermin S, Alarcón de Noya B, Losada S, Colmenares C, Hermoso T 1995a. Humoral immune response of children with chronic schistosomiasis. Isotypic recognition of adult worm antigens. Para- site Immunol 17: 319-328.

Noya O, Losada S, Alarcón de Noya B, Gonzales S, Hermoso T, Balzan C, Cesari IM 1995b. Effect of chemotherapy in immune response to egg antigens of Schistosoma mansoni in chronically infected children from areas of low transmission. Parasite Immunol 17: 111-117.

Oliver-Gonzalez J, 1954. Anti-egg precipitins in sera of humans infected with Schistosoma mansoni. J Infect Dis 95: 86-91.

Pointier JP, McCullough F 1989. Biological control of the snail hosts of Schistosoma mansoni in the Caribbean area using Thiara spp. Acta Tropica 46: 147155.

Reimer CB, Black CM, Holman RC, Wells TW, Ramirez RM, Sa-Ferreira JA, Janet KA, Nicholson JKA, McDougal JS 1988. Hypergammaglobulinemia associated with human immunodeficiency virus infection. Monogr in Allerg 23: 83-96.

Reimer CB, Smith S, Wells T, Nakamura R, Keitges P, Williams G, Hanson D, Dorsey D, 1982. Collaborative calibration of the U.S. National and American Pathologists reference preparations for specific serum proteins. Am J Clin Path 77: 12-19.

Rifaat M, Ismail I, El Mahallawy M, Awaad S, Essawy M 1969. Comparative study of some immunological tests for schistosomiasis before and after treatment. Trans $R$ Soc Trop Med Hyg 63: 338-342.

Rihet P, Demeure E, Bourgouis A, Prata A, Dessein AJ 1991. Evidence for an association between human resistance to Schistosoma mansoni and high antilarval IgE levels. Eu J Immunol 21: 2679-2686.

Rowe DS, Anderson SG, Tackett L 1970. A research standard for human serum immunoglobulin D. Bull WHO 43: 607-609.

Rowe DS, Grab B, Anderson SG 1972. An international reference preparation for human serum immunoglobulins $\mathrm{G}, \mathrm{A}$ and $\mathrm{M}$ : content of immunoglobulin by weight. Bull WHO 46: 67-69.

Rowe DS, Grab B, Anderson SG 1973. An international reference preparation for human serum immunoglobulin E. Bull WHO 49: 320-321.

Sabah AA, Fretcher C, Webbe C, Doenhoff MJ 1985. Schistosoma mansoni reduced efficacy of chemotherapy in infected T-cell deprived mice. Exp Parisit 60: $348-352$.

Tavares Neto J, Prata A 1988. Reação da forma hepato esplênica da esquistosomose em relação à raça. Rev Soc Bras Med Trop 21: 131-133.

WHO 1985. The control of schistosomiasis. World Health Organization Technical Report Series 728.

Xiao S, Catto BA, Webster LT 1985. Effects of praziquantel on different developmental stages of Schistosoma mansoni in vitro and in vivo. J Infect Dis 151: 1130-1137. 
Immunoglobulin Isotypes in Choronic Schistosomiasis - RM Ramírez et al. 